\title{
PARTISIPASI GOVERNANCE DALAM PEMBERDAYAAN PELAKU USAHA KECIL DAN MENENGAH DI KECAMATAN PASANGKAYU KABUPATEN MAMUJU UTARA
}

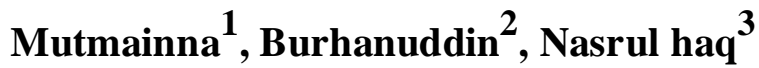 \\ 1) Ilmu Administrasi Negara Unismuh Makassar \\ 2) Ilmu Administrasi Negara Unismuh Makassar \\ 3) Ilmu Administrasi Negara Unismuh Makassar
}

\begin{abstract}
This study aimed to determine the participation of governance in empowering small and medium business actors in Pasangkayu District, North Mamuju Regency. The type of research was qualitative. The type of research was phenomenology. Data collection techniques were such as interview, observation, and documents. The result of this research was that participation in decision making had not been optimal because the training schedule was still limited. Participation in implementation, participation in benefid taking and participation in evaluation had not been maximized because there were still many communities receiving SME assistance that was not as expected. Internal factors ie human resources were running well because it could help people's lives. External factors were such as facilities and infrastructure had not been realized because the SME assistance tool provided by the Office Koperindag misused by the community.
\end{abstract}

Keywords: Participation, governance, SME empowerment

\begin{abstract}
ABSTRAK
Penelitian ini bertujuan untuk mengetahui partisipasi governance dalam pemberdayaan pelaku usaha kecil dan menengah di Kecamatan Pasangkayu Kabupaten Mamuju Utara. Jenis penelitian adalah kualitatif. Tipe penelitian adalah deskriptif. Teknik pengumpulan data yakni berupa wawancara, observasi dan dokumen. Hasil penelitian ini yaitu partisipasi dalam pengambilan keputusan belum optimal karena jadwal pelatihan yang dilaksanakan masih terbatas. Partisipasi dalam pelaksanaan, partisipasi dalam pengambilan manfaat dan partisipasi dalam evaluasi belum maksimal karena masih banyak masyarakat menerima bantuan UKM yang tidak sesuuai yang diharapkan. Faktor internal yakni SDM sudah berjalan dengan baik karena dapat membantu kehidupan masyarakat. Faktor eksternal yakni sarana dan prasarana belum terealisaikan sebab alat bantuan UKM yang diberikan oleh Dinas koperindag disalah gunakan oleh masyarakat.
\end{abstract}

Kata Kunci: Partisipasi, governance, pemberdayaan UKM 


\section{PENDAHULUAN}

Perkembangan UKM penting menyiratkan bahwa terdapat potensi yang besar atas kekuatan domestik, jika hal ini dapat dikelolah dan dikembangkan dengan baik, bahkan tentu akan dapat mewujudkan usaha menengah yang tangguh, pemerintah Indonesia telah menerbitkan program kebijakan ekonomi terpadu pada 15 September 2003, yang mencakup kebijakan fiskal, keuangan dan sektor riil serta kebijakan moneter. Kebijakan fiskal, keuangan dan sektor riil dituangkan didalam instruksi Presiden RI No. 5 Tahun 2003 tentang Paket Kebijakan Ekonomi Menjelang dan Sesudah Berakhirnya Program Kerjasama Dengan Dana Moneter Internasional (International Monetary Fund).

Secara nyata Usaha Kecil Menengah (UKM) juga sebagai sektor usaha yang berperan besar terhadap pembangunan nasional, terbukti telah mampu menciptakan peluang kerja yang cukup besar bagi tenaga kerja dalam negeri, sehingga sangat membantu dalam mengurangi jumlah pengangguran.Usaha mikro, kecil dan menengah (UMKM) merupakan basis usaha rakyat, yang secara mengejutkan mampu bertahan dimasa kritis 1997/1998.Saat itu banyak usaha besar bergelimpangan, mengalami pailit didera pahitnya krisis.Pada saat bersamaan, perbankan tidak mampu lagi membantu usaha besar karena mereka sendiri memiliki masalah pula sehingga menambah parah penderitaan usaha besar.Tidak demikian halnya dengan UKM, yang dapat bertahan pada badai krisis karena struktur keuangan mereka yang tidak banyak bergantung pada 
perbankan, meski mereka tetap Pasangkayu setiap tahun mengalami memanfaatkan jasa perbankan, baik perkembangan salah satunya adalah untuk transaksi maupun untuk perdagangan di pasar, selain menjaga keamanan.

disebabkan oleh ketahanannya juga

Sebagian besar pelaku UKM

disebabkan semakin berkembangnya

ini mengandalkan seluruh

Kabupaten Mamuju Utara.

permodalannya sendiri yang

Disadari sektor UKM masih

bersumber pada tabungan pribadi,

memerlukan pembinaan yang terus

pinjaman dari bank, kerabat atau

menerus baik dari pemerintah

tetangga bahkan tak jarang yang

(Pelatihan Manajerial, Pemasaran

perolehannya melalui pinjaman ke

lembaga keuangan bukan

dan Mutu Produk) juga yangtidak

bank.Misalnya koperasi dan lembaga

kalah penting peran dari pihak perbankan atau lembaga lainnya keuangan mikro (LKM) (Darmawan, (BUMN danBUMD) dalam rangka 2004).

memberikan akses permodalan untuk

Kabupaten Mamuju Utara mengembangkan usaha.

tepatnya di Kecamatan Pasangkayu

Pelaku UKM di Kecamatan

adalah salah satu Kecamatan yang

Pasangkayu Kabupaten Mamuju

memiliki potensi UKM yang

Utara

tidak

mampu

masihbelum tergarap maksimal

bertahanmisalnya, dari segi

seperti kota-kota lainnya.Sekalipun

kamampuan dalam mengembangkan

pada dasarnya UKM di Kabupaten

usaha, khususnya dibidang

Mamuju Utara Kecamatan

tekstil.Kemandirian

dalam 
memperbaiki taraf hidup mengenai pendapatan ekonominya masingmasing karena terhalang oleh usahausaha besar atau kapitalis.Selain itu, masyarakat juga dibatasi oleh pengetahuan dan keterampilan dasar dalam mengkreasikan motif, keterbatasan modal dan akses ke sumber permodalan yang layak, mudah, cepat dan tepat.

Disinilah fungsi pemerintah untuk membantu peningkatan taraf hidup masyarakat yang memiliki usaha kecil menengah (UKM), dan kebijakan pemerintah dalam bertanggung jawab untuk permasalahan mendasar UKM yaitu pembenahan masalah permodalan dan pemasaran yang akan memberi dampak terhadap produk dan jasa UKM sehingga mampu meningkatkan kesejahteraan masyarakat Kabupaten Mamuju Utara.

Oleh karena itu usaha kecil menengah (UKM) harus mendapat dukungan penuh oleh pemerintah agar UKM bisa lebih berkembang dan dapat membuka lapangan pekerjaan yang lebih besar lagi dan juga dapat mengurangi jumlah pengangguran dan juga agar perekonomian lebih stabil dengan adanya dari usaha kecil menengah.

Usaha kecil menengah juga terjadi hubungan diantara pemerintahan, sektor swasta, dan masyarakat, berkaitan dengan UU dan pemerintah juga membuat kebijakan terhadap UKM melalui

UU No. 9 Tahun 1995 dan terbaru UU No. 20 Tahun 2008 tentang Usaha Mikro, Kecil, dan Menengah serta turunan UU ke PP No 17 Tahun 2013 tentang pelaksanaan undang- 
undang nomor 20 tahun 2008 tentang Usaha Mikro, Kecil dan Menengah dan Peraturan Daerah Provinsi Kepulauan Riau Nomor 4 Tahun 2011 tentang Usaha Mikro, Kecil, dan Menengah.

Syahyuti dalam Mappamiring (2011:38), mengemukakan bahwa partisipasi dapat didefinisikan sebagai proses dimana seluruh pihak dapat membentuk dan terlibat dalam seluruh inisiatif pembangunan.

Menurut Cohen dan Uphoff yang dikutip oleh Astuti D (2011: 61-63), membedakan partisipasi menjadi empat jenis, yaitu Pertama, partisipasi dalam pengambilan keputusan.Kedua, partisipasi dalam pelaksanaan. Ketiga, partisipasi dalam pengambila pemanfaatan.Dan keempat, partisipasi dalam evaluasi. Pengertian partisipasi dikemukakan oleh Djalal dan
Supriadi (2001: 201-202),dimana partisipasi dapat juga berarti bahwa pembuat keputusan menyarankan kelompok atau masyarakat ikut terlibat dalam bentuk penyampaiansaran dan pendapat, barang, keterampilan, barang dan jasa, partisipasi dapat juga berarti bahwa kelompok mengenal masalah mereka sendiri, mengkaji pilihan mereka membuat keputusan dan memecahkan masalahnya.

\section{Shery Arstein (Siti Irene A.D.} 2011: 64), menjelaskan peran serta partisipasi masyarakat dalam tangga partisipasi sebagai berikut: a. Citizen power Pada tahap ini sudah terjadi pembagian hak, tanggung jawab, dan wewenang antara masyarakat dengan pemerintah dalam pengambilan keputusan.Dimana masyarakat sebagai kontrol masyarakat (citizen coontrol), pelimpahan kekuasaan 
(delegated control), dan kemitraan (parthnership).b. Tokeinisme Hanya sekedar formalitas yang memungkinkan masyarakat mendengar dan memiliki hak untuk memberikan suara, tetapi pendapat mereka belum menjadi bahan dalam pengambilan keputusan.Klasifikasi ini memiliki tingkatan penentraman (placation), konsultasi

(consultation), dan informasi

(information). c. Nonpartisipasi adalah klasifikasi yang hanya menjadikan masyarakat sekedar objek dalam pengambilan sebuah kebijakan.

Perencanaan pembangunan Partisipatif menurut Hanif Nurcholis (2008), adalah suatu model perencanaan pembangunan yang mengikut sertakan masyarakat. Masyarakat aktif melibatkan diri dalam melakukan identifikasi masalah, perumusan masalah, pencarian alternative pemecahan masalah, penyusunan agenda pemecahan, terlibat dalam proses penggondogan (konversi), ikut memantau implementasi, dan ikut aktif melakukan evaluasi.

Pemberdayaan berasal dari bahasa inggris "impowerment" yang dapat bermakna "pemberian kekuasaan" karena power bukan sekedar daya tapi juga kekuasaan sehingga kata "daya" tidak saja bermakna 'mampu' tapi juga bermakna "mempunyai kekuasaan" (Wrihartnolo dan Dwijowitono, 2007).

Farazmand dalam Falih Suaedi (2010: 45),governance merupakan solusi untuk mengatasi problema yang belum teratasi dan yaang ditimbulkan oleh OPA (Farazmand menyebutnya dengan 
traditional forms of government). Lebih lanjut ia mengungkapkan bahwa governance memiliki dua bentuk, yakni entrepreneurialmodels of government (NPM) dan social and political governance (NPS). Konsep governance tersebut kini menenrima kritik. Sebagian karena tidak semua prinsip governance dapat dijalankan dengan mulus di negara-negara sedang berkembang. Sebagian lagi karena governance dipandang sebagai konsep yang bersifat imperialistik karena dipaksakan oleh lembaga-lembaga internasional untuk diterapkan di negara-negara sedang berkembang. Dalam kondisi tertentu negara maju lebih dipandang menikmati keuntungan yang lebih besar dari terbukanya pasar bebas di negara-negara sedang berkambang akibat penggunaan prinsip governance. Apa yang dinilai baik oleh negara maju dan kaya belum tentu baik pula bagi negara yang sedang berkembang bagi administrasi publik, penggunaan NPM atau NPS hanya memanfaatkan sebahagian potensi stakeholder secara optimal dalam menyelesaikan masalah-masalah publik dan mencapai tujuan-tujuan publik dalam kondisi seperti ini.

Proses pemberdayaan umumnya dilakukan secara kolektif. Menurutnya, tidak ada literatur yang menyatakan bahwa proses pemberdayaan terjadi dalam relasi satu lawan satu antara pekerja sosial dan klien dalam setting pertolongan perseorangan. Meskipun pemberdaya an seperti ini dapat meningkatkan rasa percaya diri dan kemampuan dari klien, hal ini bukanlah strategi utama pemberdayaan.Namun demikian tidak semua intervensi 
pekerja sosial dapat dilakukan melalui kolektivitas. Dalam beberapa situasi, strategi pemberdayaan dapat saja dilakukan secara individual, meskipun pada gilirannya strategi ini pun tetap berkaitan dengan kolektivitas, dalam arti mengaitkan klien dengan sumber atau sistem lain diluar dirinya. Dalam konteks pekerjaan sosial, pemberdayaan dapat dilakukan melalui tiga aras atau matra pemberdayaan (emprowerment setting):mikro, mezzo dan makro (Edi Suharto, 2010:66).

Lebih lanjut World Bank dalam Totok Mardikanto (2015: 28), pemberdayaan dapat diartikan sebagai upaya peningkatan kemampuan masyarakat (miskin, marjinal, terpinggirkan) untuk menyampaikan pendapat dan atau kebutuhannya, pilihan-pilihannya, berpartisipasi, $\quad$ bernegosiasi, mempengaruhi dan mengelola kelembagaan masyarakatnya secara bertanggung-gugat (accountable) demi perbaikan kehidupannya.

Riki Septiawan (2012), faktor-faktor yang memperngaruhi Usaha Kecil dan Menengah yaitu: 1. Faktor internal: a. Kurangnya Permodalan dan Terbatasnya Akses Pembiayaan Permodalan, b. Kualitas Sumber Daya Manusia (SDM), c. Lemahnya Jaringan Usaha dan Kemampuan Penetrasi Pasar, d. Mentalitas Pengusaha UKM, e. Kurangnya Transparansi. 2. Faktor eksternal: a. Iklim Usaha Belum Sepenuhnya Kondusif, b. Terbatasnya Sarana dan Prasarana Usaha, c. Pungutan Liar, d. Implikasi Perdagangan Bebas, e. terbatasnya Akses Pasar, f. Terbatasnya Akses Informasi. 


\section{METODE PENELITIAN}

Penelitian ini telah di laksanakan selama 2 bulan di Kantor

Dinas Kecamatan Pasangkayu

Kabupaten Mamuju Utara. Alasan penulis memilih lokasi ini di karenakan di Kantor Kecamatan Pasangkayu Kabupaten Mamuju Utara masih banyak pelaku UKM yang belum mendapatkan partisipasi pemerintah dan mendapatkan produktivitas dan kesejahteraan para pelaku UKM Jenis penelitian menggunakan kualitatif. sumber data data penelian ini adalah data primer dan data sekunder. Informan penelitian sebanyak 7 orang. Tekhnik pengumpulan data dalam penelitian ini adalah: observasi, wawancara, dan dokumentasi.

\section{HASIL DAN PEMBAHASAN}

Partisipasi pemerintah merupakan keterlibatan pemerintah mamuju utara dalam menjalankan wewenang yang telah ditugaskan kepada mereka agar menjalankan dengan baik, indikator yang akan dilihat yaitu (a) Partisipasi dalam pengambilan keputusan, Partisipasi dalam pelaksanaan, (c) Partisipasi dalam pengambilan manfaat, dan (d) Partisipasi dalam evaluasi.

Dalam partisipasi masyarakat mengenai pemberdayaan UMKM ada beberapa faktor yang mempengaruhinya, faktor ini berdampak pada para pelaku usaha kecil dan menengah di Kecamatan Pasangkayu Kabupaten Mamuju Utara. Adapun faktor yang mempengaruhi antara lain: faktor internal yaitu sumber daya manusia, faktor eksternal yaitu sarana dan prasarana. 
Kepala Dinas Koperindag diarahkan langsung oleh tim mengadakan musyawarah dalam penyuluh dan diadakan satu kali pengambilan keputusan yang dihadiri dalam sebulan serta pelatihan ini oleh pelaku UKM dengan diadakan di tempat yang telah mengeluarkan ide-ide atau disiapkan oleh Pemerintah Daerah. pendapatnya mengenai program Tujuan dari pelatihan adalah untuk pemberdayaan UKM yang ikut memberikan atau mengarahkan mengadakan rapat atau pertemuan masyarakat pelaku UKM khususnya dan membahas mengenai masalah sebagai penjahit terhadap program UKM seperti kualitas SDM yang yang dijalankan.

masih rendah, selain itu Kepala Partisipasi yang dilakukan

Dinas Koperindag juga berupaya oleh Kepala Dinas Koperindag di meningkatkan kesejahteraan pelaku UKM serta dalam musyawarah juga Kecamatan Pasangkayu Kabupaten Mamuju Utara yaitu mengupayakan membicarakan tentang solusi untuk memberdayakan masyarakat bagaimana memberdayakan pelaku UKM dengan cara masyarakat pelaku UKM agar dapat memberikan bantuan dengan sejahtera.

mendirikan tempat yang namanya Dalam pengambilan UPT sebagai tempat kegiatan keputusan Kepala Dinas Koperindag administrasi serta kegiatan-kegiatan perlu mengadakan pelatihan kepada lain seperti musyawarah dan masyarakat pelaku UKM khususnya sebagai tukangjahit. Pelatihan pelatihan-pelatihan khusus kepada masyarakat pelaku UKM. 
Pemerintah mengharapkan agar diberikan oleh pemerintah sangat bantuan ini dapat memudahkan membantu masyarakat. Namun, masyarakat sebagai pelaku UKM Pelaku UKM merasa bantuan yang dalam menjalankan usaha dengan diberikan oleh pemerintah daerah baik dan maksimal.

belum efektif sebab dalam program Upaya pemerintah daerah ini pemerintah tidak menjelaskan Kabupaten Mamuju Utara yang ingin secara detail bahwa untuk dapat memberdayakan masyarakat pelaku menerima bantuan tersebut ada UKM sehingga Kepala Bidang UKM beberapa prosedur yang harus

mengoptimalkan dengan baik dilakukan. Seperti mengikuti bantuan yang ada yaitu UPT yang merupakan tempat melakukan berbagai pelatihan-pelatihan maupun kegiatan administrasi lainnya yang kegiatan-kegiatan administrasi, diselenggarakan oleh pemerintah. musyawarah, dan memberikan Sehingga dengan begitu bantuan pelatihan-pelatihan khusus kepada tersebut dapat diterima dan pelaku UKM dengan tujuan agar digunakan sebagaimana mestinya memudahkan masyarakat dalam oleh masyarakat.

menjalankan sebuah usaha denaik Koordinasi yang dilakukan dan maksimal sehingga dapat dengan mengadakan kerjasama meningkatkan pendapatan dan antara semua lapisan stakeholders, kesejahteraan masyarakat. swasta, dan masyarakat terkait Bantuan program program partisipasi dalam pemberdayaan UMKM yang pelaksanaan yakniberupa kegiatan 
administrasi yang berhubungan dengan pelaksanaan kegiatan program UMKM. Dengan adanya kegiatan administrasi tersebut diharapkan program pemberdayaan UMKM dapat terlaksana dengan baik, serta dengan partisipasi antara ketiga unsur tersebutdapat membantu kelancaran program bantuan UKM yang dilaksanakan oleh pemerintah daerah.Sehingga tujuan untuk membangun dan memberdayakan pelaku UKM akan berjalan dengan baik sesuai dengan yang diharapkan,baik oleh pemerintah maupun masyarakat pelaku UKM.

\section{Pelaksanaan kegiatan}

administrasi yang dilakukan oleh

pemerintah terkait program poemberdayaan masyarakat UMKM dengan melakukan pelatihanpelatihan sudah berjalan dengan baik. Namum banyak masyarakat yang belum puas dengan adanya kegiatan tersebut. Karena kurangnya sosialisasi yang dilakukan oleh pemerintah, sehingga mereka tidak mengetahui apa dan bagaimana caranya mendapatkan bantuan program UMKM tersebut.

Koordinasi yang dilakukan oleh pemerintah daerah melalui partisipasi pelaksanaan dalam pemberdayaan UKM memang sudah terlaksana oleh pemerintah daerah yakni melakukan kerjasama antara stakeholder, swasta dan masyarakat namun, kerjasama tersebut belum sepenuhnya terlaksana dengan baik. Seperti yang terjadi dalam masyarakat kecil yang tergolong sebagai masyarakat yang diberdayakan oleh pemerintah terkadang beranggapan bahwa mereka tidak mendapat perhatian dari pemerintah. Mereka juga merasa 
bahwa apa yang diharapkan dari pemerintah tidak sesuai dengan kenyataan yang ada. Seharusnya

pemerintah, swasta dan masyarakatberada pada titik koordinasi yang sama dengan bekerjasama yang baik sehinggapelaku UKM juga dapat memahami dan menerima apa yang

diberikan oleh pemerintah.Jika kerjasama yang terjalin antara pemerintah dan masyarakat UKM berjalan baik, maka diharapkan dapat memberikan hasil yang

memuaskan terkait program pemberdayaan UKM tersebut.

Kerjasama yang dijalin antara berbagai pihak yang bersangkutan dalam pemberdayaan masyarakat pelaku UKM diharapkan dapat memberikan manfaat khususnya kepada pelaku UKM itu sendiri. Pemerintah daerah dalam hal ini
Kepala Dinas UMKM berpartisipasi dalam program pemberdayaan UKM dengan tujuan untuk meningkatkan pendapatan masyarakat kecil yang tadinya berada di bawah garis kemiskinan kemudian dapat meningkat. Kerjasama yang dijalin dari semua pihak yang bersangkutan mulai dari musyawarah yang

dilakukan untuk mengetahui berbagai permasalahan yang dihadapi untuk menemuukan solusi, koordinasi dilakukan dengan tujuan agar kerjasama selalu berjalan dengan baik, pelatihan-pelatihan serta pengawasan dilakukan agar masyarakat pelaku UKM dapat berdaya dan memiliki penghasilan yang baik.

Kepala Dinas Koperindag berharap agar masyarakat yang ada di Kecamatan Pasangkayu Kabupaten Mamuju Utara memiliki 
lapangan pekerjaan sehingga Kepala

Dinas Koperindag mengeluarkan

program khususnya kepada

masyarakat pelaku UKM agar

masyarakat bisa menjalankan usaha-

usahanya sehingga tidak ada lagi

pengangguran atau masyarakat yang

tidak memiliki pekerjaan khususnya

di Kecamatan Pasangkayu

Kabupaten Mamuju Utara.

Dalam sebuah organisasi

sering terjadi konflik antara atasan

dan bawahan atau antar sesama oleh

karena itu pemerintah daerah

mengupayakan untuk selalu

mengawasi setiap kegiatan yang

dilaksanakan dalam program

pemberdayaan masyarakat pelaku

UKM. Pengawasan yang dijalankan

pemerintah daerah sesuai dengan

jadwal yakni setiap pagi pada pukul

07.30-09.00 dan pada sore hari yaitu

pukul 14.30-16.00. Tujuan dari pengawasan tersebut untuk

mengawasi masyarakat pelaku UKM

yang ingin menggunakan bantuan

yang disediakan di UPT agar tidak

terjadi kesalahan maupun

kecurangan untuk itu masyarakat

pelaku UKM yang menerima

bantuan tersebut didaftar dalam buku

administrasi terlebih dahulu sehingga

bantuan yang diberikan dapat

digunakan dengan baik sesuai

dengan harapan.

Pemerintah daerah

melakukan upaya penanggulangan

terhadap masyarakat khususnya

pelaku UKMuntuk mengatasi

pengangguran yang ada di

Kecamatan Pasangkayu Kabupaten

Mamuju Utara. Upaya

penanggulangan ini diharapkan dapat

meminimalisir angka pengangguran

sehingga kemiskinan di daerah ini

dapat diatasi secara optimal. 
Kualitas SDM sangat penting bagi seseorang khususnya pembina dalam hal ini seluruh instansi

pemerintah yang memiliki

wewenang dalam program

pemberdayaan UKM sehingga dalam pelaksanaan program dapat berjalan dengan baik dan mencapai tujuan yang diinginkan.

Secara etimologi memiliki perbedaan, namun keduanya memiliki keterkaitan yang sangat penting sebagai alat penunjang keberhasilan suatu proses yang dilakukan. Dengan demikian suatu proses kegiatan yang akan dilakukan tidak akan mencapai hasil yang diharapkan sesuai dengan rencana jika sarana dan prasarana tidak tersedia.

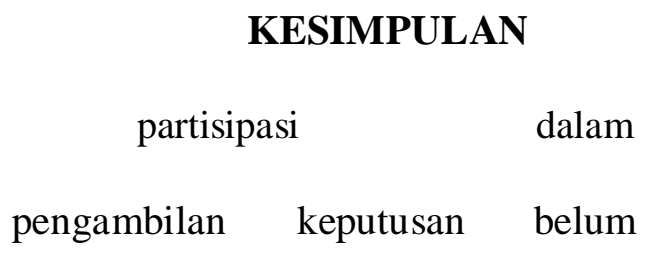

optimal karena jadwal pelatihan yang dilaksanakan masih terbatas. Partisipasi dalam pelaksanaan, partisipasi dalam pengambilan manfaat dan partisipasi dalam evaluasi belum maksimal karena masih banyak masyarakat menerima bantuan UKM yang tidak sesuai dengan yang diharapkan. Faktor internal yakni sumber daya manusia sudah berjalan dengan baik karena dapat membantu kehidupan masyarakat. Faktor eksternal yakni sarana dan prasarana belum terealisaikan sebab alat bantuan UKM yang diberikan oleh Dinas koperindag disalah gunakan oleh masyarakat.

Dari kesimpulan di atas, maka perlu dikemukakan beberapa saran sebagai berikut: pelunya peningkatan pemahaman terhadap masyarakat akan pentingnya ikut 
berpartisipasi dalam program pemberdayaan UKM agar usaha yang dijalankan sesuai dengan harapan termasuk dallam pelatihan, pembinaan maupun memberikan pengetahuan serta bantuan agar usaha masyarakat semakin meningkat.

\section{DAFTAR PUSTAKA}

Djalal, Fasli dan Dedi Supriadi. 2001. Reformasi Pendidikan dalam Konteks Otonomi Daerah. Yogyakarta: Adicita Karya.

Dwiningrum, Siti Irene Astuti. 2011. Desentralisasi dan Partisipasi Masyarakat dalam Pendidikan. Yogyakarta: Pustaka Pelajar.

Mappamiring. 2011. Partisipatif Manajemen Pengelolaan. Makassar: $\quad$ YAPMA Makassar.

Mardikanto, Totok, Soebianto, Poerwoko. 2015. Pemberdayaan Masyarakat dalam Perspektif Kebijakan Publik. Bandung: Alfabeta.

Nurcholis, Hanif. 2008. Perencanaan Partisipatif Pemerintah Daerah. Jakarta: Grasindo.
Septiawan, Riki. 2012. Makalah: Identifikasi Perkembangan Usaha Kecil di Indonesia dan Permasalahan yang dihadapinya. Bandung.

Suaedi, Falih, Wardiyanto, Bintoro. 2010. REFITALISASI ADMINISTRASI NEGARA (Reformasi Birokrasi dan eGovernance). Yogyakarta: Graha Ilmu.

Suharto, Edi. 2010. Membangun Masyarakat Memberdayakan Rakyat. Bandung: Refika Aditama.

Sundariningrum.2001. Partisipasi Masyarakat. Yogyakarta:Pelajar.

Wrihatnolo, R. R. dan Riant Nugroho Dwijowitono. 2007. Manajemen Pemberdayaan Sebuah Pengantar dan Panduan Untuk Pemberdayaan Masyarakat. Jakarta: PT Elex Media kupotindo. 